\title{
ANALISIS SISTEM SIMPAN PINJAM KOPERASI KARYA TAMA MANDIRI KECAMATAN MUARA BELITI KABUPATEN MUSI RAWAS
}

\author{
Oleh: Meliani Purwanti ${ }^{1}$, Ikbal Barlian ${ }^{2}$, Riswan Aradea ${ }^{3}$ \\ melianipurwanti01@gmail.com¹, riswanaradea@gmail.com³ \\ (Program Studi Pendidikan Akuntansi, FKIP Universitas PGRI Palembang)
}

\begin{abstract}
Abstrak-Tujuan penelitian ini untuk mengetahui Sistem Simpan Pinjam Koperasi Karya Tama Mandiri. Metode dalam penelitian ini menggunakan metode Kualitatif. Hasil penelitian menunjukkan bahwa pada Sistem Simpan Pinjam Koperasi Karya Tama Mandiri Kecamatan Muara Beliti Kabupaten Musi Rawas dapat dijelaskan bahwa (1) Sistem Simpan Pinjam pada koperasi Karya Tama Mandiri Kecamatan Muara Beliti Kabupaten Musi Rawas, besar simpanan pokok Rp. 5000,- dan besar simpanan wajib Rp. 20.000,- sedangkan simpanan sukarela, tidak memiliki ketetapan jumlah dalam nominalnya. Pada sistem pinjaman, setiap anggota koperasi diberi batas uang pinjaman mulai dari Rp. 1.000.000,- sampai dengan Rp. 20.000.000,- kecuali bagi yang meminjam uang menggunakan jaminan surat berharga dapat meminjam uang lebih dari Rp. 20.000.000,pinjaman uang pada Koperasi Karya Tama Mandiri dikenakan bunga sebesar $2 \%$.
\end{abstract}

Kata Kunci: Sistem Simpan Pinjam Koperasi

Abstract-The purpose of this study was to determine the Cooperative Savings and Loan System of Karya Tama Mandiri. The method in this study uses a qualitative method. The results showed that the Karya Tama Mandiri Cooperative Savings and Loan System of Muara Beliti District Musi Rawas Regency can be explained that (1) the Savings and Loan System at the Karya Tama Mandiri cooperative Muara Beliti District Musi Rawas Regency, the principal amount of Rp. 5000, and the amount of mandatory savings is Rp. 20,000, while voluntary savings do not have a fixed amount in nominal value. In the loan system, each cooperative member is given a loan limit starting from Rp. 1,000,000 up to Rp. 20,000,000, except for those who borrow money using securities guarantees can borrow more than Rp. 20,000,000.- money loans to the Karya Tama Mandiri Cooperative bear interest of $2 \%$.

Keywords: Cooperative Savings and Loans System

\section{PENDAHULUAN}

Perkembangan koperasi dewasa ini sangatlah pesat, hampir seluruh lembaga pemerintahan maupun swasta bahkan sampai pada masyarakat telah menjadi anggota koperasi seperti menjadi anggota Koperasi Unit Desa (KUD), anggota Koperasi Kredit Himpunan Usaha Bersama (KOPDIT HUB), anggota Koperasi Pegawai Republik Indonesia (KOPPRI) dan anggota 
koperasi lainnya. Karena koperasi merupakan lembaga yang menjalankan suatu kegiatan usaha dan pelayanan yang sangat membantu perekonomian anggotanya dan masyarakat. Kegiatan usaha yang dimaksudkan dapat berupa pelayanan, perkreditan, pemasaran dan kegiatan lainnya. Berdasarkan pasal 3 UU No. 25 tahun 1992 Koperasi bertujuan untuk memajukan kesejahteraan anggotanya, untuk memajukan kesejahteraan masyarakat dan turut serta membangun tatanan perekonomian nasional.

Dalam pasal 3 UU No.25/1992, tujuan koperasi berbunyi "Koperasi bertujuan memajukan kesejahteraan anggota pada khususnya dan masyarakat pada umumnya serta ikut membangun tatanan perekonomian nasional dalam rangka mewujudkan masyarakat yang maju, adil, dan makmur berlandaskan Pancasila dan UUD 1945."

Ciri-ciri koperasi menurut pasal 4 UU No. 25 Tahun 1992 menyatakan tentang fungsi dan peran koperasi, yaitu : 1) membangun dan mengembangkan potensi dan kemampuan ekonomi anggota pada khususnya dan masyarakat pada umumnya, untuk meningkatkan kesejahteraan ekonomi sosialnya. 2) berperan secara aktif dalam upaya mempertinggi kualitas kehidupan manusia dan masyarakat. 3) memperkokoh perekonomian rakyat sebagai dasar kekuatan dan ketahanan perekonomian nasional dengan Koperasi sebagai sokogurunya. 4) berusaha mewujudkan dan mengembangkan perekonomian nasional yang merupakan usaha bersama berdasarkan atas asas kekeluargaan dan demokrasi ekonomi. (UU RI No. 25 Th 1992 tentang perkoperasian, 2009:4).

Menurut Anoraga, widiyanti (2007:18), jenis-jenis koperasi terbagi menjadi 5 golongan, yaitu: 1) koperasi konsumsi, 2) koperasi kredit (koperasi simpan pinjam), 3) koperasi produksi, 4) koperasi jasa, dan 5) koperasi serba usaha. Sedangkan menurut "Rachmawati (2017:28) selain jenis-jenis koperasi di atas ada juga koperasi sekolah".

"Salah satu cara pembentukan modal pada koperasi adalah melalui simpanan, baik simpanan pokok maupun simpanan wajib, juga berbagai simpanan lain, seperti dana, hibah, serta modal penyertaan (Muljono, 2012:195), jadi simpanan dalam koperasi adalah salah satu sumber permodalan koperasi yang berasal dari anggota. Simpanan dalam koperasi dapat juga diartikan sebagai setoran uang tunai anggota dalam jumlah tertentu kepada koperasi sebagai tabungan bagi anggota dan sebagai sumber modal bagi koperasi.

Koperasi terdiri dari berbagai macam jenis unit usaha seperti Koperasi Konsumsi, Koperasi Produksi, Koperasi Pemasaran, serta 
Koperasi Kredit/Simpan Pinjam, salah satu unit usaha yang paling maju adalah unit simpan pinjam atau Koperasi Simpan Pinjam. Kegiatan pokok unit ini adalah menerima simpanan dari anggota dan memberikan pinjaman kepada anggota yang memerlukan dana. Salah satu koperasi yang memiliki unit usaha simpan pinjam adalah Koperasi Simpan Pinjam Karya Tama Mandiri Kecamatan Muara Beliti Kabupaten Musi Rawas.

Kegiatan Koperasi Karya Tama Mandiri di Kecamatan Muara Beliti Kabupaten Musi Rawas berlangsung dari awal berdirinya sampai dengan sekarang, dari aktivitas koperasi diketahui bahwa terdapat anggota dari koperasi Karya Tama Mandiri yang meminjam uang kemudian terlambat membayar uang pinjaman, sedangkan uang simpanan, dan tagihan dari anggota koperasi tidak sebanding dengan jumlah yang dipinjam. Hal ini menjadi masalah bagi Koperasi Karya Tama Mandiri di Kecamatan Muara Beliti Kabupaten Musi Rawas karena dapat menyebabkan kurangnya modal pada Koperasi Karya Tama Mandiri, sehingga jika ada anggota lain dari Koperasi Karya Tama Mandiri ingin meminjam uang akan terhambat serta di khawatirkan dapat menyebabkan Koperasi Karya Tama Mandiri mengalami penurunan dalam pembagian Sisa Hasil Usaha (SHU).

Hasil wawancara awal yang peneliti lakukan pada Koperasi Karya Tama Mandiri Kecamatan Muara Beliti Kabupaten Musi Rawas, bahwa terdapat kendala yang dihadapi pengelola koperasi dalam hal penyimpanan dan peminjaman uang. Kendala tersebut menyangkut dua aspek, yaitu (1) peminjaman uang di bank dengan nominal yang besar tanpa konsultasi terlebih dahulu ke petugas koperasi hal tersebut dapat menyebabkan gaji menjadi minus (2) meminjam mengatas namakan anggota koperasi. Permasalahan tersebut harus segera diatasi karena apabila tidak segera diatasi maka Koperasi Karya Tama Mandiri Kecamatan Muara Beliti Kabupaten Musi Rawas dikhawatirkan seluruh aktivitasnya terancam mengalami kemunduran.

Tujuan penelitian ini adalah untuk mengetahui Sistem Simpan Pinjam pada Koperasi Karya Tama Mandiri Kecamatan Muara Beliti Kabupaten Musi Rawas Tahun 2015/2016. Dengan diketahuinya Sistem Simpan Pinjam di koperasi ini, hasil penelitian ini akan memberikan solusi pada Sistem Simpan Pinjam yang seharusnya dijalankan oleh Koperasi Karya Tama Mandiri di Kecamatan Muara Beliti Kabupaten Musi Rawas.

\section{METODE PENELITIAN}

Metode penelitian yang digunakan adalah metode kualitatif. "Metode Kualitatif adalah metode penelitian yang berlandaskan pada filsafat postpositivisme, digunakan untuk meneliti pada kondisi obyek yang alamiah, (sebagai lawannya adalah metode eksperimen) dimana peneliti adalah sebagai instrument kunci, teknik pengumpulan data dilakukan dengan dua cara yaitu dokumentasi, dan wawancara, analisis data bersifat induktif atau kualitatif dan hasil penelitian kualitatif lebih menekankan makna 
dari pada generalisasi (Sugiyono, 2015:9)".

Teknik pengumpulan data yang peneliti gunakan dalam penelitian ini ada 2 cara yaitu Dokumentasi dan Wawancara. Dokumentasi adalah mencari data mengenai hal-hal atau variabel yang berupa catatan, transkrip buku, surat kabar, majalah, prasasti, notulen rapat, lengger, agenda, dan sebagainya (Arikunto, 2014:274).

Wawancara digunakan sebagai teknik pengumpulan data apabila peneliti ingin melakukan studi pendahuluan yang menemukan permasalahan yang harus diteliti, dan juga apabila peneliti ingin mengetahui hal-hal dari responden yang lebih mendalam dan jumlah respondennya sedikit atau kecil (Sugiyono, 2015:137). Pada penelitian ini, wawancara ditujukan kepada ketua serta pengurus koperasi Karya Tama Mandiri Kecamatan Muara Beliti Kabupaten Musi Rawas.

Untuk menetapkan keabsahan (Trustworthiness) data diperlukan teknik pemeriksaan, pelaksanaan teknik pemeriksaaan didasarkan atas sejumlah kriteria tertentu.(Menurut Sugiyono, 2015: 270-277) ada empat kriteria yang digunakan yaitu derajat kepercayaaan

(Credibelity), keteralihan (Transferability), Kebergantungan (Dependability). Dan kepastian (Confirmability).

\section{HASIL DAN PEMBAHASAN}

Penelitian yang dilakukan di koperasi Karya Tama Mandiri. Tujuan penelitian ini adalah untuk mengetahui Sistem Simpan Pinjam pada Koperasi Karya Tama Mandiri di Kecamatan Mauara Beliti
Kabupaten Musi Rawas. Guna mencapai tujuan tersebut peneliti melakukan penelitian dengan menggunakan observasi, angket, dokumentasi dan wawancara sebagai teknik pengumpulan data.

Sistem Simpan Pinjam pada Koperasi Karya Tama Mandiri Kecamatan Muara Beliti Kabupaten Musi Rawas merupakan suatu proses transaksi dalam bidang keuangan yang ditujukan bagi seluruh anggota koperasi yang terikat di Instansi Pemerintahan atau Pegawai Negeri Sipil khusus peminjaman uang. Sedangkan penyimpanan uang pada koperasi Karya Tama Mandiri Kecamatan Muara Beliti Kabupaten Musi Rawas, hanya dilakukan dari dana simpanan pokok, simpanan wajib, simpanan sukarela dan dana hibah.

Dari data dokumentasi tahun 2015-2016 diketahui bahwa secara umum simpanan pokok anggota koperasi yang masuk pada kas koperasi pada tahun 2015 sebesar Rp. 10.180.009,00,- mengalami peningkatan menjadi Rp. 28.855.685,00. Uang simpanan wajib di tahun 2015 sebesar Rp. 26.880.000,00,- meningkat menjadi Rp. 27.360.000,- di tahun 2016. Simpanan sukarela di tahun 2015 sebesar Rp. 124.992.158,- meningkat menjadi Rp. 140.380.354,- di tahun 2016. Simpanan wajib pada tahun 2015 sebesar Rp. 6.780.000,meningkat menjadi Rp. 6.840.000,di tahun 2016.

Hasil analisis data dokumentasi dapat bahwa simpanan pokok dan simpanan wajib anggota koperasi Karya Tama Mandiri tidak mengalami penunggakan dalam sistem penyimpanannya, dalam hal 
ini simpanan pokok sebesar Rp.5000,- dan simpanan wajib sebesar Rp.20.000,- langsung mendapatkan potong melalui gaji pegawai, yang dikhususkan pada anggota Koperasi Karya Tama Mandiri Kecamatan Muara Beliti Kabupaten Musi Rawas.

Dari data observasi, angket dan wawancara dapat dilihat hasil diketahui bahwa perlunya jaminan bagi anggota yang akan meminjam, berdasarkan angket yang ditujukan kepada ketua koperasi dengan hasil persentase $100 \%$, peminjam harus memiliki jaminan, dikuatkan dengan hasil wawancara dengan ketua koperasi Karya Tama Mandiri yang dapat dijadikan jaminan surat-surat berharga, seperti surat tanah, surat rumah, dalam hal ini koperasi Karya Tama Mandiri telah sesuai dengan Peraturan Menteri Negara Koperasi dan Usaha Kecil dan Menengah Republik Indonesia Nomor : 10/Per/M.KUKM/XI/2008 pasal 21 tentang Jaminan.

Dalam aktivitasnya, pemberian simpan pinjam koperasi Karya Tama Mandiri belum aman dari resiko kecurangan dan penipuan, berdasarkan angket yang ditujukan kepada ketua koperasi dengan hasil persentase $100 \%$, dikuatkan dengan hasil wawancara dengan ketua koperasi Karya Tama Mandiri bahwa ada anggota meminjam uang dalam jangka waktu 1 bulan, ternyata dalam proses pengembalian uang pinjaman lebih dari 5 bulan. Oleh karena itu koperasi Karya Tama Mandiri sebaiknya lebih menekankan kreteria bagi anggota yang meminjam uang, agar simpan pinjam dapat berjalan dengan efektif dan efisien dan terhindar dari resiko kecurangan serta penipuan.

Perlunya sanksi bagi anggota yang mengalamai macet pengembalian uang pinjaman sesuai dengan maksimal waktu yang ditentukan dalam keadaan mutasi kerja, berdasarkan angket yang ditujukan kepada ketua koperasi dengan hasil persentase $100 \%$, dikuatkan dengan hasil wawancara dengan ketua koperasi Karya Tama Mandiri bahwa sanksinya diberi peringatan awal seperti teguran melalui via komunikasi, maka suratsurat berharga yang dijadikan jaminan akan ditahan jika anggota meminjam lebih dari Rp.20.000.000,00, atau gaji yang akan di tahan oleh bendahara jika meminjam kurang dari Rp. 20.000.000,00. Dalam hal ini tindakan yang dilakukan oleh pihak koperasi Karya Tama Mandiri telah sesuai, agar anggota tidak menyepelekan atas pinjaman yang mereka lakukan.

Perlunya persetujuan dari atasan dalam pemberian pinjaman, berdasarkan angket yang ditujukan kepada pengurus koperasi dengan hasil persentase $100 \%$, dikuatkan dari hasil observasi bahwa adanya persetujuan dari atasan dalam pemberian pinjaman, kemudian diperoleh dari hasil wawancara diketahui bahwa pada koperasi Karya Tama Mandiri memberikan pinjaman kepada anggotanya disesuaikan dengan besarnya potongan gaji, apabila gaji pegawai atau anggota telah minus maka pinjaman ke koperasi tak bisa dilakukan. Menurut Peraturan Menteri Negara Koperasi dan Usaha Kecil dan Menengah Republik Indonesia Nomor: 
20/Per/M.KUKM/XI/2008 tentang pedoman penilaian kesehatan koperasi Simpan Pinjam dan Unit Simpan Pinjam Koperasi. Dalam hal ini koperasi telah memberikan peraturan yang baik sesuai dengan Peraturan Menteri Negara Koperasi dan Usaha Kecil dan Menengah Republik Indonesia Nomor: 20/Per/M.KUKM/XI/2008, jika tetap diberikan pinjamannya maka akan mengalami kredit macet.

Adanya anggota yang mengajukan surat pinjaman, tetapi masih memiliki tunggakan di koperasi Karya Tama Mandiri, berdasarkan angket yang ditujukan kepada pengurus koperasi dengan hasil persentase jawaban ya sebanyak $66,67 \%$, sedangkan jawaban tidak sebanyak 33,34\%, dikuatkan dari hasil wawancara kepada pengurus koperasi Karya Tama Mandiri diketahui bahwa pada koperasi Karya Tama Mandiri memiliki besar jumlah pinjaman mulai dari Rp. 1.000.000,00 sampai dengan Rp. 20.000.000,00.

Perlunya strategi, jika salah satu anggota yang meminjam uang di koperasi mengalami mutasi kerja, berdasarkan angket yang ditujukan kepada pengurus koperasi dengan hasil persentase $100 \%$, dikuatkan dari hasil wawancara kepada pengurus koperasi Karya Tama Mandiri diketahui bahwa pada koperasi Karya Tama Mandiri jika ada anggota yang mengalami mutasi kerja maka pegawai yang mengalami mutasi tersebut harus lapor ke ketua dan harus melunasi piutangnya.

Perlunya bunga pinjaman bagi anggota yang akan meminjam, berdasarkan angket yang ditujukan kepada pengurus koperasi dengan hasil persentase $100 \%$, dikuatkan dari hasil wawancara kepada pengurus koperasi Karya Tama Mandiri diketahui bahwa pada koperasi Karya Tama Mandiri memiliki bunga pinjaman sebesar $2 \%$.

Adanya sistem peminjaman uang dikoperasi Karya Tama Mandiri, berdasarkan angket yang ditujukan kepada anggota koperasi dengan hasil persentase jawaban ya sebanyak 91,59\%, sedangkan jawaban tidak sebanyak $8,42 \%$, dikuatkan dari hasil wawancara kepada anggota koperasi Karya Tama Mandiri diketahui bahwa besar pinjaman yang dilakukan oleh salah satu anggota pada koperasi Karya Tama Mandiri adalah sebesar Rp. 15.000.000,00. Menurut Muljono pinjaman merupakan produk utama, pemberian jumlah simpanan ini juga di tentukan oleh pengurus koperasi, dan juga menurut Peraturan Menteri Usaha Kecil dan Menengah pinjaman adalah penyediaan uang atau tagihan yang di persamakan dengan itu, berdasarkan persetujuan dan kesepakatan antara pinjaman dengan yang meminjam antara koperasi dengan pihak lain dalam hal ini adalah anggota dengan pengurus koperasi Karya Tama Mandiri. Dapat disimpulkan bahwa pemberian pinjaman yang di lakukan pada Koperasi Karya Tama Mandiri ini sudah di kategorikan baik karena telah sesuai dengan Teori para ahli dan Peraturan Menteri Koperasi Usaha Kecil dan Menengah yaitu memberikan pinjaman berdasarkan atas kesepakatan antara anggota peminjam dan pengurus yang meminjamkan yang di sesuaikan 
dengan kemampuan koperasi dalam besarnya pinjaman.

Perlunya persyaratan dalam mengajukan permohonan pinjaman pada koperasi Karya Tama Mandiri, berdasarkan angket yang ditujukan kepada anggota koperasi dengan hasil persentase $100 \%$, dikuatkan dari hasil wawancara kepada anggota koperasi Karya Tama Mandiri diketahui bahwa persayaratan yang dilakukan anggota untuk melakukan permohonan pinjaman pada koperasi Karya Tama Mandiri adalah dengan mengisi formulir, tanda tangan di atas materai, tanda tangan persetujuan dari pengurus serta ketua koperasi Karya Tama Mandiri, sedangkan menurut Menteri Koperasi Usaha Kecil dan Menengah permohonan pinjaman dilakukan dengan cara anggota mengisi formulir 2 rangkap yang asli diberikan kepada petugas KSP dan fotocopyannya di pegang oleh calon peminjam, petugas simpan pinjam harus memberikan petujuk serta bimbingan bagi calon peminjam dalam pengisian formulir agar data yang diberikan benar dan dapat di pertanggung jawabkan, proses permohonan ini dapat diteruskan apabila formulir dan data yang diperlukan telah lengkap dan tidak ada permasalahan lagi. Dapat disimpulkan dari hasil wawancara yang peneliti lakukan bahwa persyaratan untuk melakukan permohonan pinjaman yang dilakukan di koperasi Karya Tama Mandiri.

Anggota sebaiknya rutin dalam setiap bulan melakukan simpanan sukarela, berdasarkan angket yang ditujukan kepada anggota koperasi dengan hasil persentase jawaban ya sebanyak $71,79 \%$, sedangkan jawaban tidak sebanyak 28,04\%, dikuatkan dari hasil wawancara kepada anggota koperasi Karya Tama Mandiri diketahui bahwa simpanan pada koperasi Karya Tama Mandiri terdiri dari 2 simpanan, simpanan Wajib dan simpanan sukarela, simpanan wajib langsung mendapat potongan dari gaji perbulan sebesar Rp. 20.000,00, sedangkan simpanan sukarelanya sebesar Rp. 1.000.000,00, dimana menurut Menteri Koperasi Usaha Kecil dan Menegah persyaratan dalam melakukan pinjaman adalah calon pinjaman harus mempunyai simpanan aktif. Dapat disimpulkan bahwa yang dilakukan koperasi Karya Tama Mandiri ini sudah sesuai dengan peraturan Menteri Koperasi Usaha Kecil dan Menengah.

Adanya tujuan anggota dalam melakukan pinjaman di koperasi Karya Tama Mandiri, berdasarkan angket yang ditujukan kepada anggota koperasi dengan hasil persentase $100 \%$, dikuatkan dari hasil wawancara kepada anggota koperasi Karya Tama Mandiri bahwa tujuan pinjaman pada koperasi Karya Tama Mandiri yang dilakukan oleh anggota adalah sebagai modal usaha, serta bayaran angsuran pendidikan anak.

Adanya dampak positif bagi dari penyimpanan uang pada koperasi Karya Tama Mandiri, berdasarkan angket yang ditujukan kepada anggota koperasi dengan hasil persentase $100 \%$, dikuatkan dari hasil wawancara kepada anggota koperasi Karya Tama Mandiri bahwa bahwa dampak positifnya untuk meningkatkan SHU pada koperasi Karya Tama Mandiri. Menurut UU 
No.25/1992 tentang perkoperasian bahwa SHU bukanlah pendapatan yang berupa keuntungan yang dipetik dari hasil menanamkan saham yang seperti yang terjadi pada prusahaan, namun SHU merupakan keuntungan usaha yang di bagi sesuai dengan aktivitas ekonomi anggota koperasi sehingga besaran SHU yang di terima oleh setiap anggota akan berbeda, besar kecilnya nominal yang didapat dari SHU tergantung dari besarnya partisipasi modal dan transaksi anggota terhadap pembentukan pendapatan koperasi. Dapat disimpulkan bahwa dampak positif penyimpanan uang pada koperasi Karya Tama Mandiri yang di lakukan oleh anggota adalah dapat meningkatkan Sisa Hasil Usahanya.

Kendala dalam meminjam uang di koperasi Karya Tama Mandiri, berdasarkan angket yang ditujukan kepada anggota koperasi dengan hasil persentase jawaban ya sebanyak 94,40\%, sedangkan jawaban tidak sebanyak 5,61\%, dikuatkan dari hasil wawancara kepada anggota koperasi Karya Tama Mandiri diketahui bahwa kendala dalam meminjam uang di koperasi Karya Tama Mandiri adalah Kendalanya anggota yang meminjam uang lebih banyak dari pada anggota yang melakukan pengembalian uang pinjaman di Koperasi Karya Tama Mandiri, dalam hal ini dapat memperhambat sistem pinjaman di koperasi Karya Tama Mandiri. Dalam hal ini jika tidak segera di antisipasi maka Koperasi Karya Tama Mandiri dalam sistem Simpan Pinjamnya akan mengalami pinjaman bermasalah. menurut Subagyo (2014:44) tentang Kebijakan penanganan pinjaman bermasalah menjelaskan tentang kriteria Pinjaman Bermasalah dan Penanganan Pinjaman Bermasalah.

\section{KESIMPULAN}

Berdasarkan hasil penelitian yang peneliti lakukan di Koperasi Karya Tama Mandiri Kecamatan Muara Beliti Kabupaten Musi Rawas mengenai Sistem Simpan Pinjam anggota, maka dapat disimpulkan :

1. Sistem Simpan Pinjam pada koperasi Karya Tama Mandiri Kecamatan Muara Beliti Kabupaten Musi Rawas, besar simpanan pokok Rp. 5000,- dan besar simpanan wajib Rp. 20.000,- sedangkan simpanan sukarela, tidak memiliki ketetapan jumlah dalam nominalnya. Pada sistem pinjaman, setiap anggota koperasi diberi batas uang pinjaman mulai dari Rp.1.000.000,- sampai dengan Rp.20.000.000,- kecuali bagi yang meminjam uang menggunakan jaminan surat berharga dapat meminjam uang lebih dari Rp. 20.000.000,pinjaman uang pada Koperasi Karya Tama Mandiri dikenakan bunga sebesar $2 \%$.

2. Dalam sistem simpan pinjam pada koperasi Karya Tama Mandiri ada beberapa hal yang perlu di perhatikan seperti : (a) Perlunya jaminan bagi anggota yang akan meminjam, dengan hasil persentase $100 \%$, peminjam harus memiliki jaminan. (b) Pemberian simpan pinjam koperasi Karya Tama Mandiri belum aman dari resiko kecurangan dan penipuan, dengan hasil persentase $100 \%$. 
(c) Perlunya sanksi bagi anggota yang mengalamai macet pengembalian uang pinjaman sesuai jangka waktu yang ditentukan dalam keadaan mutasi kerja, dengan hasil persentase $100 \%$. (d) Perlunya persetujuan dari atasan dalam pemberian pinjaman, dengan hasil persentase $100 \%$. (e) Adanya anggota yang mengajukan surat pinjaman, tetapi masih memiliki tunggakan, dengan hasil persentase ya 66,67\%, sedangkan tidak 33,34. (f) Perlunya strategi, jika salah satu anggota yang meminjam uang di koperasi mengalami mutasi kerja, dengan hasil persentase $100 \%$. (g) Perlunya bunga pinjaman bagi anggota yang akan meminjam, dengan hasil persentase $100 \%$. (h) Adanya sistem peminjaman uang dikoperasi Karya Tama Mandiri, dengan hasil persentase ya $91,59 \%$, sedangkan tidak $8,42 \%$.

(i) Perlunya persyaratan dalam mengajukan permohonan pinjaman pada koperasi Karya Tama Mandiri, dengan hasil persentase 100\%. (j) Anggota sebaiknya rutin dalam setiap bulan melakukan simpanan sukarela, dengan hasil persentase ya $71,79 \%$, sedangkan tidak 28,04\%. (k) Adanya tujuan anggota dalam melakukan pinjaman di koperasi Karya Tama Mandiri, dengan hasil persentase $100 \%$. (1) Adanya dampak positif bagi dari penyimpanan uang pada koperasi Karya Tama Mandiri, dengan hasil persentase $100 \%$. (m) Adanya kendala dalam meminjam uang di koperasi Karya Tama Mandiri, dengan hasil persentase ya $94,40 \%$, sedangkan tidak 5,61\%.

\section{DAFTAR PUSTAKA}

Arikunto, Suharsimi. (2014). Prosedur Penelitian. Jakarta : PT Rineka Cipta.

Barlian, Ikbal dan Koryati. (2016). Penelitian Tindak Kelas.

Palemabang: UNSRI.

Rachmawati, Diana Widi. (2017).

Kinerja Keuanagan Koperasi

Pelajar SMK Negeri 3

Palembang Dilihat dari Rasio Solvabilitas. Jurnal Neraca: Jurnal Pendidikan dan Ilmu Ekonomi Akuntansi. Volume 1 Nomor 1 (2017) hal. 27-35. DOI:

http://dx.doi.org/10.31851/nera ca.v1i1.1164.

Muljono, Djoko. (2012). Buku Pintar Strategi Bisnis Koperasi Simpan Pinjam. Yogyakarta: ANDI.

Subagyo, Ahmad. (2014). Manajemen Koperasi Simpan Pinjam. Jakarta: Mitra Wacana Media.

Sugiyono. (2015). Metode Penelitian Kuantitatif Kualitatif dan $R \& D$. Bandung : Alfabeta.

Widiyanti, Ninik, dan Anoraga Pandji. (2007). Dinamika Koperasi. Jakarta: PT Asdi Mahasatya. 